\title{
Complement Activation: The role in Health and Disease and Strategies of Therapeutic Complement Inhibition
}

\author{
Nayareen Akhtar ${ }^{1, *}$, Rezwanur Rahman ${ }^{2}$, Shahin Sultana ${ }^{1}$, Nurun Nahar Mawla ${ }^{1}$ \\ ${ }^{1}$ Department of Microbiology, Delta Medical College \& Hospital, Dhaka, Bangladesh \\ ${ }^{2}$ Department of Nephrology, BSMMU, Dhaka, Bangladesh \\ *Corresponding author: nayareen07@gmail.com
}

Received October 15, 2014; Revised November 10, 2014; Accepted November 21, 2014

\begin{abstract}
The multiple interconnections among complement proteins, immune cells, and mediators provide an excellent mechanism to protect the organism against infections and support the repair of damaged tissues. However, disturbances in this "defense machinery" contribute to the pathogenesis of various diseases. The role of complement in various inflammatory disorders is multifaceted; for example, the activation of complement can significantly contribute to inflammation-mediated tissue damage, whereas inherited or acquired complement deficiencies highly favor the development of autoimmunity. Complement as an essential component of the immune system is of substantial relevance for the destruction of invading microorganisms and for maintaining tissue homeostasis including the protection against autoimmune diseases. The involvement of complement in the pathogenesis of a great number of partly life threatening diseases defines the importance to develop inhibitors which specifically interfere with its deleterious action. Endogenous soluble complement-inhibitors, antibodies or low molecular weight antagonists, either blocking key proteins of the cascade reaction or neutralizing the action of the complementderived anaphylatoxins have successfully been tested in various animal models over the past years.
\end{abstract}

Keywords: complement, inflammatory disorders, inhibitors, therapy

Cite This Article: Nayareen Akhtar, Rezwanur Rahman, Shahin Sultana, and Nurun Nahar Mawla, "Complement Activation: The role in Health and Disease and Strategies of Therapeutic Complement Inhibition." American Journal of Medical Sciences and Medicine, vol. 2, no. 6 (2014): 115-121. doi: 10.12691/ajmsm-2-6-1.

\section{Introduction}

The complement system plays a fundamental role in innate immunity in addition to enhancing adaptive immune responses and is therefore a primary line of defence against infection following injury. The soluble components of complement are present not only in the circulation but also in body fluids and tissues, ready to engage in defense reactions triggered by exogenous (eg, infectious agents) or endogenous (eg, ischemia, autoimmunity) stimuli that could cause cell injury. Today, complement should rather be viewed as a system that orchestrates and connects various responses during immune and inflammatory reactions and not merely as a killer of bacteria. [1] However, excessive or uncontrolled complement activation significantly contributes to undesired tissue damage. The interactions between the complement system and proinflammatory cytokines are reciprocal. Several reports have suggested that proinflammatory cytokines enhance the expression of anaphylatoxin receptors in inflammatory cells. [2,3] Complement activation following ischemiareperfusion(I/R) is associated with myocardial infarction [4], atherosclerosis [5], intestinal ischemia [6], hemorrhagic shock [7], sepsis 8and pulmonary injury [9]. The formation of immune complexes is one of the principal ways of activating the classical pathway of the complement system. C1q triggers the activation process of the complement system when it binds to immune complexes, bridges the innate and adaptive immune systems. When antigens meet $\mathrm{B}$ cells in the presence of complement, the threshold for activation of the B cell is lowered. [10] The complement system has an important role in clearing immune complexes from the circulation [11]. It can also bind to apoptotic cells and helps to eliminate these cells from tissue. [12,13] If the complement system fails in this function, waste material can accumulate and evoke an autoimmune response. [15] Activation of the complement system has been proven to participate in the pathogenesis of a number of diseases. $[14,15]$.

\section{Organization and Regulation of the Complement System}

The complement system is subdivided into three pathways: the classical, alternative and more recently described lectin complement pathway (LCP). Activation of these pathways occurs sequentially through the proteolytic cleavage and association of precursor molecules. Classical complement pathway activation occurs when antibody/antigen complexes interact with the first complement component, $\mathrm{C} 1$, leading to the 
generation of C1q. C1q can then bind to the Fc portion of complexed immunoglobulins resulting in activation of the $\mathrm{C} 1 \mathrm{r}$ and $\mathrm{C} 1 \mathrm{~s}$ esterase sub-components of $\mathrm{C} 1$, and ultimately the formation of a C3 convertase. The alternative complement pathway is an antibodyindependent pathway activated by a variety of mechanisms including yeast cell walls (zymosan), biomaterials (i.e., cardiopulmonary bypass and hemodialysis tubing), and tissue type plasminogen activator. The LCP is also an antibody-independent pathway activated by binding of mannose-binding lectin (also known as mannan/mannose binding protein; MBL) to carbohydrate structures present on the surface of bacteria, yeast, parasitic protozoa, and viruses [16].

All three pathways merge at C3, where it is cleaved into $\mathrm{C} 3 \mathrm{a}$ and $\mathrm{C} 3 \mathrm{~b}$, and $\mathrm{C} 5$ is subsequently cleaved to form C5a and C5b. Addition of C6, C7, C8 and multiple C9 units to $\mathrm{C} 5 \mathrm{~b}$ results in formation of the terminal complement complex, C5b-9. Following complement activation, biologically active peptides, such as C5a and C3a elicit a number of proinflammatory effects, including the recruitment of leukocytes, degranulation of phagocytic cells, mast cells and basophils, smooth muscle contraction, and increase of vascular permeability. Upon complementdependent cell activation, the inflammatory response is further amplified by subsequent generation of toxic oxygen radicals and the induction of synthesis and release of arachidonic acid metabolites and cytokines. The complement system acts as a rapid first-line defence against pathogen invasion by opsonisation and lytic destruction [17].

Under physiological conditions, activation of complement is effectively controlled by the coordinated action of soluble as well as membrane-associated regulatory proteins. Soluble complement regulators, such as C1-inhibitor, anaphylotoxin inhibitor (serum carboxypeptidase N), C4b binding protein (C4BP), factors Hand I, clusterin and S-protein (vitronectin), restrict the action of complement in body fluids at multiple sites of the cascade reaction. In addition, each individual cell is protected against the attack of homologous complement by surface proteins, such as the complement receptor1 (CR1, CD35), the membrane cofactor protein (MCP, CD46) as well as by the glycosylphosphatidylinositol (GPI)-anchored proteins, decay-accelerating factor (DAF, CD55) and CD59. When complement is improperly activated, these regulatory mechanisms may be overwhelmed, resulting in tissue destruction and disease [18].

\section{Complement in Inflammatory Disorders}

The complement system seems to be a major contributor to the tissue damage that occurs after ischemia and reperfusion. Complement activation following ischemia/reperfusion occurs during myocardial infarction $[19,20]$; ischemia of the intestine, [21] hind limb, [22] and kidney [23] hemorrhagic shock [24]; sepsis [25]; and pulmonary injury. [26] The list of such conditions is rapidly growing, including immune-complex diseases such as rheumatoid arthritis and systemic lupus erythematosus, ischemia-reperfusion (I/R) injury locally manifested as infarctions or systemically as a postischemic inflammatory syndrome, systemic inflammatory response syndrome (SIRS) and acute respiratory distress syndrome (ARDS), septic shock, trauma, burns, acid aspiration to then lungs, renal diseases, inflammatory and degenerative diseases in the nervous system, arteriosclerosis, transplant rejection and inflammatory complications seen after cardiopulmonary bypass and haemodialysis. In principle, when inflammation is involved in the pathogenesis, complement has to be considered as a possible mediator in the disease process. [27] As yet there is no definitive answer to the question of how complement is activated after I/R. It seems that all three pathways of complement activation are involved in the initiation of the proteolytic cleavage of complement cascade components. Whatever the mechanism of activation, the components of complement are often deposited on the surface of endothelial cells. The endothelium, together with the underlying basement membrane, builds a vascular barrier, which has particular significance for the pathogenesis of I/R injury. [28] It has been postulated that natural antibodies reacting with antigen epitopes that are exposed after damage to endothelial cells play an important role in the activation of complement during I/R injury. [29] iC3b, formed by the proteolytic cleavage of $\mathrm{C} 3 \mathrm{~b}$ deposited on the endothelial surface, acts as a ligand for $\beta 2$ integrin CD11b/CD18 (CR3). This adhesion molecule is up-regulated in activated leukocytes and contributes to the accumulation of these cells in the extravascular compartment. The deposition of several complement proteins on the surface of endothelium ultimately leads to the formation of terminal complement complex, which, when incorporated into the cellular membrane, activates endothelial nuclear factor $\kappa \mathrm{B}$. Thereby, it increases the transcription and expression of several adhesion molecules, including vascular cell adhesion molecule-1, intracellular adhesion molecule-1, and E- and P-selectins. [30] Terminal complement complex also stimulates the endothelium to produce IL-8 and monocyte chemoattractant protein-1 and directly affects vascular tone by inhibiting endotheliumdependent relaxation and decreasing endothelial cyclic guanosine monophosphate. [31] Terminal complement complex also induces the activation of platelets, contributing to platelet-leukocyte aggregation. [32] Anaphylatoxins C3a and C5a activate endothelial cells and leukocytes. C5a, more potent as an inflammatory mediator than C3a, up-regulates the expression of adhesion molecules on endothelium and induces the release of various cytokines, including IL-1, IL-6, monocyte chemoattractant protein-1, and TNF- $\alpha$. [33,34]. C5a is also a strong chemoattractant, contributing to the accumulation of inflammatory cells at the site of injury. [35] Studies in animals support functional relationships between complement activation and the pathogenesis of atherosclerosis and thrombosis. In rabbits fed a high-fat diet, C5b-9 expression was detected in the intima preceding monocyte infiltration and foam cell formation [36], and C5b-9 also impaired endothelium-dependent vasorelaxation [37], indicating a role for complement activation in endothelial dysfunction and the early stages of atheroma formation. Also in high-fat fed rabbits, the extent of atherosclerosis was greatly reduced in C6deficient compared with wild-type (WT) animals [38], 
supporting a functional role for the C5b-9 complex in the development and progression of atherosclerosis.

\section{The Complement System and Cardiovascular Disease}

Despite more than two decades of study, the role of complement in I/R injury is not fully understood. Initial observations by Hill and Ward in a rat model of permanent coronary artery occlusion demonstrated that the ischemic heart produced a protease that cleaved C3 and stimulated leukocyte activation and chemotaxis. [39] Several studies have demonstrated that complement activity is upregulated during the acute phase of MI. [40,41,42] A number of prospective and case control studies have reported strong relationships between several complement components and cardiovascular outcomes. Studies have shown that C3 predicts future cardiovascular events in men and women $[43,44,45,46]$, and case control studies have shown that C3 is elevated in patients with CVD, independent of conventional cardiovascular risk factors including CRP $[47,48,49]$. Plasma C3 and C5a predict increased intima-media thickness in patients with systemic lupus erythematosus (SLE) [50], and C5a predicts future cardiovascular events in patients with peripheral arterial disease [51], suggesting that complement activation contributes to progression of atherosclerosis and acute thrombotic events [52].

\section{Selected Diseases Related Dysfunction of Complement System}

It was evidenced that deficiencies of various complement components have a negative impact on immunity in animals, including humans. [53]. In the case of deficiencies of C3, principally increased susceptibility is recorded to infections caused by Hemophilus influenzae, Streptococcus pneumoniae and Streptococcus pyogenes. [54] Furthermore, deficiency of components C3, C1, C2 or $\mathrm{C} 4$ is related to the occurrence of suppurative infections, while deficiency of components C5-C9, MBL, as well as components of alternative pathway, namely factors B, D and $\mathrm{P}$ of properdin, results in increased risk of infections caused by Neisseria sp. [54,55] Infections caused by Neisseria meningitidis may also be a result of defects in the functioning of MAC, or deficiency of components necessary to generate it. [53] In rheumatic diseases, such as SLE (systemic lupus erythematosus) or juvenile idiopathic arthritis (JIA), there are genetically conditioned deficiencies of complement components, which makes it difficult not only to eliminate immunological complexes, but also contributes to their deposition in tissues, and thus to sustaining the inflammatory processes. [54] The studies indicated that the deficit of components C1, C2, C4 or MBL is related to the development of SLE, yet according to other authors, deficiency of components to the lectin pathway, in particular MBL and C3, rather contributes to the development of circulatory system diseases or arteriosclerosis. [56] Deficiency of C1q or C2 components may lead to the development of other autoimmunological diseases, e.g. the focal form of lupus erythematosus, glomerulonephritis, dermatomyosytis, or scleroderma. $[57,58,59]$ The complement system is also becoming increasingly implicated in diseases of the central nervous system such as Alzheimer's disease and other neurodegenerative conditions such as spinal cord injuries. [60] It is thought that the complement system might play a role in many diseases with an immune component, such as Barraquer-Simons Syndrome, asthma, glomerulonephritis, various forms of arthritis, autoimmune heart disease, multiple sclerosis, inflammatory bowel disease, paroxysmal nocturnal hemoglobinuria, atypical hemolytic uremic syndrome [61,62] and rejection of transplanted organs. [63] Mutations in the complement regulators factor $\mathrm{H}$ and membrane cofactor protein have been associated with atypical hemolytic uremic syndrome. $[64,65]$ Polymorphisms of complement component 3, complement factor $\mathrm{B}$, and complement factor $\mathrm{I}$, as well as deletion of complement factor H-related 3 and complement factor H-related 1 also affect a person's risk of developing age-related macular degeneration. [66] Mutations in the C1 inhibitor gene can cause hereditary angioedema, an autoimmune condition resulting from reduced regulation of the complement pathway $[67,68]$.

\section{Therapeutic Inhibition of the Complement System}

Excessive complement activation resulting in organ injury is associated with a variety of human pathological conditions. The effectiveness of complement inhibition or depletion in preventing tissue injury following oxidative stress has been established in many animal models. One of the first recombinant complement inhibitors was soluble CR1 (sCR1), also known as TP10. Weisman et al developed this molecule, which comprises the entire extracellular domain of CR1, and showed that it inhibited formation of C3 and C5 convertases in vivo. [69] Administration of soluble complement receptor 1 (CR1), a C3 convertase inhibitor, significantly reduces the size of an experimental myocardial infarct. In an isolated rat model of ischemia-reperfusion injury, sCR1 was able to prevent post-ischemic myocardial contractile dysfunction and enhance coronary blood flow. [70] Couser et al studied complement inhibition in three different animal models of complement-mediated glomerulonephritis. [71] In these models, administration of sCR1 were able to reduce the morphologic and functional characteristics of renal disease, as measured by mesangiolysis, glomerular infiltration by platelets and macrophages, and proteinuria. Similarly, sCR1 reduced tissue injury in ischemia/reperfusion of mouse skeletal muscle [72], rat intestine [73], rat liver [74], and remote organs after lower torso ischemia in the rat [75]. sCR1 has been shown to reduce complement-mediated tissue injury in animal models with a wide range of human acute and chronic inflammatory diseases. These include dermal vascular reactions [76,77], lung injury [78,79], trauma [80], myasthenia gravis [81], multiple sclerosis [82], allergic reactions [83], and asthma [84]. In addition, sCR1 protects against vascular injury and cellular infiltration in allografts $[85,86]$ and attenuates hyperacute rejection in xenografts. [87,88,89] Soluble recombinant MCP and DAF have also been developed and have been shown to 
inhibit complement both in vitro and in vivo [90,91]. Soluble versions of DAF (sDAF) have been shown to inhibit complement activation in the reversed passive Arthus reaction in guinea pigs [90]. Studies of the role of complement activation in myocardial ischemia and reperfusion [92,93] have used C1 inhibitor in feline [94], rat [95], and pig [96] models. All these studies have demonstrated that blocking the classical pathway of complement activation by C1 inhibitor is an effective means of protecting ischemic myocardial tissue from reperfusion injury. Similarly, a recombinant single-chain antibody against human C5 (pexelizumab) attenuates leukocyte activation, myocardial injury, and acute postoperative mortality in patients undergoing cardiopulmonary bypass surgery. [97] Using anti-C5a antibody or anti-C5aR cyclic peptide can reverse neutrophil paralysis and, more importantly, can increase survival in animals with severe sepsis [98]. It was shown that the systemic administration of the anti-C5 mAb in mice blocked complement activation, prevented the onset of arthritis in immunized animals, and ameliorated established disease. [99] Many others compound are currently undergoing clinical trials, and anticomplement therapies seem to be a novel and promising approach to minimizing the consequences of I/R-associated diseases [100].

The majority of approaches to inhibit complement has focused on either blocking at the level of C3 implying a general and broad inhibition of the system, or on selective blocking of $\mathrm{C} 5$ activation with subsequent inhibition of C5a and C5b-9 (TCC) formation (Figure 1).

\section{Classical pathway Lectin pathway Alternative pathway \\ Ag-Ab complexes Others: e.g. CRP \\ Microbial surfaces (mannose) \\ Others: e.g. $\operatorname{Ig} A$ \\ Spontaneous/amplification Foreign surfaces}

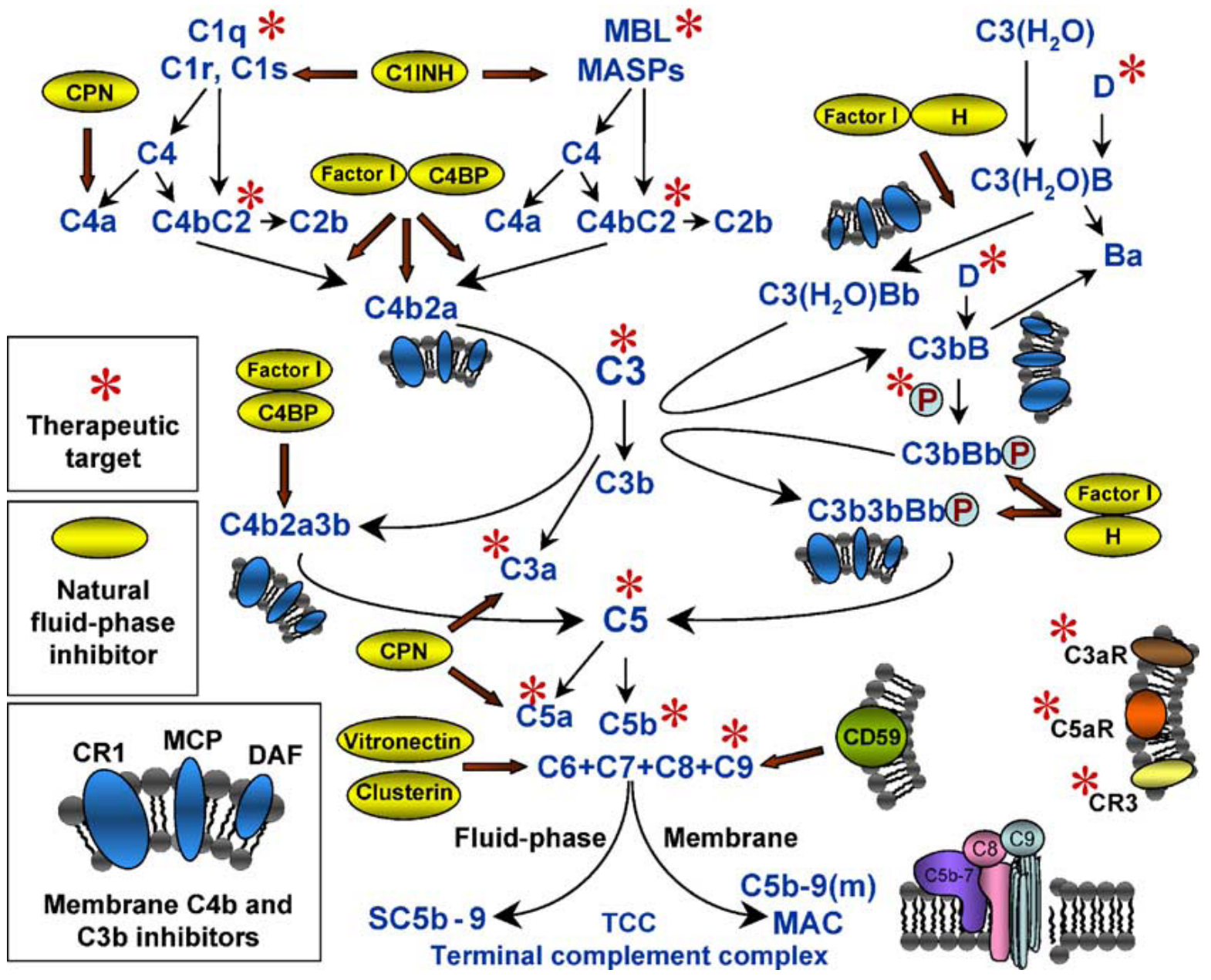

Figure 1. Potential sites in the complement cascade to be inhibited

\section{Concluding Remarks}

These complex associations of complement raise essential questions regarding therapeutic approaches to patients with inflammatory disorders. It seems to inhibit complement has becomes more valid for current therapy than it was in the past. Our knowledge of the complement system supports the design of therapeutics that could specifically inhibit complement components at various activation steps, block reciprocal complement receptors, or prevent the generation of complement effectors.

\section{References}

[1] Basu S, Binder RJ, Suto R, Anderson KM, Srivastava PK Necrotic but not apoptotic cell death releases heat shock proteins, which deliver a partial maturation signal to dendritic cells and activate the NF-אB pathway. Int Immunol. 2000; 12: 1539-1546. 
[2] Janeway CA Jr, Travers P, Walport M, Shlomchik MJ, editors. New York: Garland Publishing,; Innate immunity. Immunobiology. 2005: pp 37-100.

[3] Mastellos D, Lambris JD. Cross-disciplinary research stirs new challenges into the study of the structure, function and systems biology of complement. Lambris JD, editor. New York: Springer Science and Business Media, LLC,; Current Topics in Complement. 2006: pp 1-16.

[4] Hill, J.H., Ward, P.A., 1971. The phlogistic role of C3 leukotactic fragments in myocardial infarcts in rats. J. Exp. Med. 133, $885 \pm 900$.

[5] Vlaicu, R., Rus, H.G., Niculescu, F., Cristea, A., 1985. Immunoglobulins and complement components in human aortic atherosclerotic intima. Atherosclerosis 55, 35 \pm 50 .

[6] Fruchterman, T.M., Spain, D.A., Wilson, M.A., Harris, P.D., Garrison, R.N., 1998. Complement inhibition prevents gut ischemia and endothelial cell dysfunction after hemorrhage/resuscitation. Surgery 124, 782 \pm 791 .

[7] Spain, D.A., Fruchterman, T.M., Matheson, P.J., Wilson, M.A.,Martin, A.W., Garrison, R.N., 1999. Complement activation mediates intestinal injury after resuscitation from hemorrhagic shock. J. Trauma. 46, 224 \pm 233 .

[8] Lubbe, A.S., Garrison, R.N., Harris, P.D., 1994. Endotheliumdependent microvascular responses to activated complement. J.Surg. Res. 57, 654 \pm 660 .

[9] Mulligan, M.S., Schmid, E., Beck-Schimmer, B., Till, G.O., Friedl, H.P., Brauer, R.B., Hugli, T.E., Miyasaka, M., Warner, R.L., Johnson, K.J., Ward, P.A., 1996. Requirement and role of C5a in lung inammatory injury in rats. J. Clin. Invest. 98, 503 \pm 512 .

[10] Dempsey PW, Allison ME, Akkaraju S, Goodnow CC, Fearon DT. C3d of complement as a molecular adjuvant: bridging innate and acquired immunity. Science 1996; 271: 348e50.

[11] Davies KA, Schifferli JA, Walport MJ. Complement deficiency and immune complex disease. Springer Semin Immunopathol 1994; 15: 397e416.

[12] Korb LC, Ahearn JM. C1q binds directly and specifically to surface blebs of apoptotic human keratinocytes: complement deficiency and systemic lupus erythematosus revisited. J Immunol 1997; 158: 4525e8.

[13] Taylor PR, Carugati A, Fadok VA, Cook HT, Andrews M, Carroll MC, et al. A hierarchical role for classical pathway complement proteins in the clearance of apoptotic cells in vivo. J Exp Med 2000; 192: 359e66.

[14] Holers VM, Thurman JM. The alternative pathway of complement in disease:opportunities for therapeutic targeting. Mol Immunol 2004; 41: 147e52.

[15] Holers VM. The spectrum of complement alternative pathwaymediated diseases. Immunol Rev 2008; 223: 300e16.

[16] Turner, M.W., 1996. Mannose-binding lectin: the pluripotent molecule of the innate immune system. Immunol. Today 17 , $532 \pm 540$.

[17] Scaffidi P, Misteli T, Bianchi ME. Release of chromatin protein HMGB1 by necrotic cells triggers inflammation. Nature. 2002; 418:191-195.

[18] Szebeni, J. (Ed.), 2004. The Complement System: Novel Roles in Health and Disease. Kluwer Academic Publishers, Massachusetts.

[19] Weisman HF, Bartow T, Leppo MK, Marsh HC, Jr, Carson GR, Concino MF, Boyle MP, Roux KH, Weisfeldt ML, Fearon DT. Soluble human complement receptor type 1: in vivo inhibitor of complement suppressing post-ischemic myocardial inflammation and necrosis. Science. 1990; 249: 146-151.

[20] Jordan JE, Montalto MC, Stahl GL. Inhibition of mannose-binding lectin reduces post ischemic myocardial reperfusion injury. Circulation. 2001; 104: 1413-1418.

[21] Zhao H, Montalto MC, Pfeiffer KJ, Hao L, Stahl GL. Murine model of gastrointestinal ischemia associated with complementdependent injury. J Appl Physiol. 2002; 93: 338-345.

[22] Kyriakides C, Austen W, Jr, Wang Y, Favuzza J, Kobzik L, Moore FD, Jr, Hechtman HB. Skeletal muscle reperfusion injury is mediated by neutrophils and the complement membrane attack complex. Am J Physiol. 1999; 277: C1263-C1268.

[23] Thurman JM, Ljubanovic D, Edelstein CL, Gilkeson GS, Holers VM. Lack of a functional alternative complement pathway ameliorates ischemic acute renal failure in mice. J Immunol. 2003; 170: 1517-1523.

[24] Spain DA, Fruchterman TM, Matheson PJ, Wilson MA, Martin AW, Garrison RN. Complement activation mediates intestinal injury after resuscitation from hemorrhagic shock. J Trauma. 1999; 46: 224-233.

[25] Czermak BJ, Sarma V, Pierson CL, Warner RL, Huber-Lang M, Bless NM, Schmal H, Friedl HP, Ward PA. Protective effects of C5a blockade in sepsis. Nat Med. 1999; 5: 788-792.

[26] Mulligan MS, Schmid E, Beck-Schimmer B, Till GO, Friedl HP, Brauer RB, Hugli TE, Miyasaka M, Warner RL, Johnson KJ, Ward PA. Requirement and role of C5a in acute lung inflammatory injury in rats. J Clin Invest. 1996; 98: 503-512.

[27] Mollnes, T.E., Song, W.C., Lambris, J.D., 2002. Complement in inflammatory tissue damage and disease. Trends Immunol. 23, 6164.

[28] Weisman HF, Bartow T, Leppo MK, Marsh HC, Jr, Carson GR, Concino MF, Boyle MP, Roux KH, Weisfeldt ML, Fearon DT. Soluble human complement receptor type 1: in vivo inhibitor of complement suppressing post-ischemic myocardial inflammation and necrosis. Science. 1990; 249: 146-151.

[29] Zhang M, Takahashi K, Alicot EM, Vorup-Jensen T, Kessler B, Thiel S, Jensenius JC, Ezekowitz RA, Moore FD, Carroll MC. Activation of the lectin pathway by natural IgM in a model of ischemia/reperfusion injury. J Immunol. 2006; 177: 4727-4734.

[30] Collard CD, Lekowski R, Jordan JE, Agah A, Stahl GL. Complement activation following oxidative stress. Mol Immunol. 1999; 36: 941-Nicholson-Weller A, Halperin JA. Membrane signaling by complement C5b-9, the membrane attack complex. Immunol Res. 1993; 12: 244-257.

[31] Nicholson-Weller A, Halperin JA. Membrane signaling by complement C5b-9, the membrane attack complex. Immunol Res. 1993; 12: 244-257.

[32] .Sims PJ, Wiedmer T. The response of human platelets to activated components of the complement system. Immunol Today. 1991; 12: 338-342.

[33] Schindler R, Gelfand JA, Dinarello CA. Recombinant C5a stimulates transcription rather than translation of interleukin-1 (IL1) and tumor necrosis factor: translational signal provided by lipopolysaccharide or IL-1 itself. Blood. 1990; 76: 1631-1638.

[34] Albrecht EA, Chinnaiyan AM, Varambally S, Kumar-Sinha C, Barrette TR, Sarma JV, Ward PA. C5a-induced gene expression in human umbilical vein endothelial cells. Am J Pathol. 2004; 164: 849-859.

[35] Dreyer WJ, Michael LH, West MS, Smith CW, Rothlein R, Rossen RD, Anderson DC, Entman ML. Neutrophil accumulation in ischemic canine myocardium: insights into time course, distribution, and mechanism of localization during early reperfusion. Circulation. 1991; 84: 400-411.

[36] P. S. Seifert, F. Hugo, G. K. Hansson, and S. Bhakdi, "Prelesional complement activation in experimental atherosclerosis. Terminal C5b-9 complement deposition coincides with cholesterol accumulation in the aortic intima of hypercholesterolemic rabbits,” Laboratory Investigation, vol. 60, no. 6, pp. 747-754, 1989. View at Scopus.

[37] P. F. Lennon, C. D. Collard, M. A. Morrissey, and G. L. Stahl, "Complement-induced endothelial dysfunction in rabbits: mechanisms, recovery, and gender differences,” American Journal of Physiology, vol. 270, no. 6, pp. H1924-H1932, 1996. View at Scopus.

[38] W. Schmiedt, R. Kinscherf, H. P. Deigner et al., "Complement C6 deficiency protects against diet-induced atherosclerosis in rabbits," Arteriosclerosis, Thrombosis, and Vascular Biology, vol. 18, no. 11, pp. 1790-1795, 1998.

[39] Hill, J.H., Ward, P.A., 1971. The phlogistic role of C3 leukotactic fragments in myocardial infarcts in rats. J. Exp. Med. 133, $885 \pm 900$.

[40] M. Yasuda, K. Takeuchi, M. Hiruma et al., "The complement system in ischemic heart disease," Circulation, vol. 81, no. 1, pp. 156-163, 1990.

[41] P. F. Langlois and M. S. Gawryl, "Detection of the terminal complement complex in patient plasma following acute myocardial infarction," Atherosclerosis, vol. 70, no. 1-2, pp. 95105, 1988.

[42] R. C. Go, G. Olson, R. T. Acton et al., "Association of factor B with ischemic heart disease (IHD)," Progress in Clinical and Biological Research, vol. 147, pp. 479-480, 1984. V

[43] A. Muscari, C. Bozzoli, G. M. Puddu et al., "Association of serum C3 levels with the risk of myocardial infarction,” American Journal of Medicine, vol. 98, no. 4, pp. 357-364, 1995.

[44] G. Engström, B. Hedblad, L. Janzon, and F. Lindgärde et al., "Complement C3 and C4 in plasma and incidence of myocardial 
infarction and stroke: a population-based cohort study, Journal of Cardiovascular Prevention and Rehabilitation, vol. 14, no. 3, pp. 392-397, 2007.

[45] G. Széplaki, Z. Prohászka, J. Duba et al., “Association of high serum concentration of the third component of complement (C3) with pre-existing severe coronary artery disease and new vascular events in women,” Atherosclerosis, vol. 177, no. 2, pp. 383-389, 2004.

[46] A. Muscari, G. Massarelli, L. Bastagli et al., "Relationship of serum C3 to fasting insulin, risk factors and previous is chaemicevents in middle-aged men,” European Heart Journal, vol. 21, no. 13, pp. 1081-1090, 2000.

[47] R. Ajjan, P. J. Grant, T. S. Futers et al., "Complement C3 and Creactive protein levels in patients with stable coronary artery disease," Thrombosis and Haemostasis, vol. 94, no. 5, pp. 1048 1053, 2005.

[48] A. Onat, B. Uzunlar, G. Hergenç et al., "Cross-sectional study of complement C3 as a coronary risk factor among men and women," Clinical Science, vol. 108, no. 2, pp. 129-135, 2005.

[49] A. M. Carter, U. K. Prasad, and P. J. Grant, "Complement C3 and C-reactive protein in male survivors of myocardial infarction," Atherosclerosis, vol. 203, no. 2, pp. 538-543, 2009.

[50] R. Huey, C. M. Bloor, M. S. Kawahara, and T. E. Hugli, "Potentiation of the anaphylatoxins in vivo using an inhibitor of serum carboxypeptidase N (SCPN). I. Lethality and pathologic effects on pulmonary tissue,” American Journal of Pathology, vol. 112, no. 1, pp. 48-60, 1983.

[51] W. S. Speidl, M. Exner, J. Amighi et al., "Complement component C5a predicts future cardiovascular events in patients with advanced atherosclerosis,” European Heart Journal, vol. 26, no. 21, pp. 2294-2299, 2005.

[52] Rua-Figueroa, O. Arencibia-Mireles, M. Elvira et al., "Factors involved in the progress of preclinical atherosclerosis associated with systemic lupus erythematosus: a 2-year longitudinal study," Annals of the Rheumatic Diseases, vol. 69, no. 6, pp. 1136-1139, 2010.

[53] Dunkelberger JR, Song WC (2010): Complement and its role in innate and adaptive immune responses. Cell Research 20: 34-50.

[54] Kowalski ML: Clinincal immunology. Publ. MEDITON. Łódź 2000 (in Polish). Brown KM, Sacks SH, Sheerin NS (2007): Mechanisms of disease: the complement system in renal injurynew ways of looking at an old foe. Nat Clin Pract Nephrol 3: 277286.

[55] Sjoholm AG, Jonsson G, Braconier JH et al. (2006): Complement deficiency and disease: an update. Mol Immunol 43: 78-85.

[56] Manderson AP, Botto M, Walport MJ. The role of complement in the development of systemic lupus erythematosus. Annu Rev Immunol. 2004; 22: 431-456.

[57] Koide M, Shirahama S, Tokura Y, Takigawa M, Hayakawa M, Furukawa F. Lupus erythematosus associated with C1 inhibitor deficiency. J Dermatol. 2002; 29: 503-507.

[58] Engel AG, Hohlfeld R, Banker BQ. The polymyositis and dermatomyositis syndromes. In: Engel AG, Franzini-Armstrong C, editors. Myology. 2nd ed.New York: McGraw-Hill; 1994. p. 1335-83.

[59] Miller GW, Nussenzweig V. A new complement function: solubilization of antigen-antibody aggregates. Proc Natl Acad Sci U S A 1975; 72: 418-22.

[60] Galvan MD, Luchetti S, Burgos AM, et al. (December 2008). "Deficiency in complement $\mathrm{C} 1 \mathrm{q}$ improves histological and functional locomotor outcome after spinal cord injury". $J$. Neurosci. 28 (51): 13876-88.

[61] Arumugam et al.; Shiels, IA; Woodruff, TM; Granger, DN; Taylor $S M$ (2004). "The role of the complement system in ischemiareperfusion injury". Shock 21 (5): 401-9.

[62] Naesens $M$, Li L, Ying L, Sansanwal P, Sigdel TK, Hsieh SC, Kambham N, Lerut E, Salvatierra O, Butte AJ, Sarwal MM. (2009). "Expression of Complement Components Differs Between Kidney Allografts from Living and Deceased Donors". J. Am. Soc. Nephrol. 20 (8): 1839-1851.

[63] Sacks $S$ et al. (2003). "Role of the complement system in rejection". Curr. Opin. Immunol. 21 (5): 487-92.

[64] Goicoechea de Jorge E, Harris CL, Esparza-Gordillo J, Carreras L, Arranz EA, Garrido CA, López-Trascasa M, Sánchez-Corral P, Morgan BP, Ródriguez de Córdoba S. Gain-of-function mutations in complement factor B are associated with atypical hemolytic uremic syndrome. Proc Natl Acad Sci USA. 2007; 104: 240-245.
[65] Dragon-Durey MA, Frémeaux-Bacchi V (2005). "Atypical hemolytic uremic syndrome and mutations in complement regulator genes". Springer Semin. Immunopathol. 27 (3): 359-74.

[66] Thurman JM, Holers VM. The central role of the alternative complement pathway in human disease. J Immunol. 2006; 176: 1305-1310.

[67] Ferraro, M. F.; Moreno, A. S.; Castelli, E. C.; Donadi, E. A.; Palma, M. S.; Arcuri, H. A.; Lange, A. P.; Bork, K.; Sarti, W.; Arruda, L. K. Allergy. Oct 2011, Vol. 66 Issue 10, p 1384-1390. 7 p. 2 Diagrams, 1 Chart.

[68] Bafunno, Valeria; Bova, Maria; Loffredo, Stefania; Divella, Chiara; Petraroli, Angelica; Marone, Gianni; Montinaro, Vincenzo; Margaglione, Maurizio; Triggiani, Massimo. Annals of Human Genetics. Mar 2014, Vol. 78 Issue 2, p 73-82. 10 p.

[69] Weisman HF, Bartow T, Leppo MK, et al. Soluble human complement receptor type 1: in vivo inhibitor of complement suppressing post ischemic myocardial inflammation and necrosis. Science. 1990b; 249: 146.

[70] Shandelya SML, Kuppusamy P, Herskowitz A, Weisfeldt ML, Zweier JL (1993) Soluble complement receptor type 1 inhibits the complement pathway and prevents contractile failure in the postischemic heart: Evidence that complement activation is required for neutrophil-mediated reperfusion injury. Circulation 88 : 2812-2826.

[71] Couser WG, Johnson RJ, Young BA, et al. The effects of soluble recombinant complement receptor 1 on complement-mediated experimental glomerulonephritis. J Am Soc Nephrol. 1995; 5: 1888-94.

[72] .Pemberton M, Anderson G, Vetvicka V, Justus DE, Ross GD (1993)Microvascular effects of complement blockade with soluble recombinant CR1 on ischemia/reperfusion injury of skeletal muscle. J Immunol 150: 5104-5113.

[73] Hill J, Lindsay TF, Ortiz F, Yeh CG, Hechtman HB, Moore FD, Jr (1992) Soluble complement receptor type 1 ameliorates the local and remote organ injury after intestinal ischemia-reperfusion in the rat. J Immunol 149: 1723-1728.

[74] Chávez-Cartaya R, Cozzi E, Pino-DeSola G, Jamieson NV, White DJ (1995) Regulation of complement activation in rat liver ischemia and reperfusion: Expression of endothelial CD59 (RIP). Transplant Proc 27: 2852-2854.

[75] Lindsay TF, Hill J, Ortiz F, Rudolph A, Valeri CR, Hechtman HB, Moore FD, Jr. (1992) Blockade of complement activation prevents local and pulmonary albumin leak after lower torso ischemiareperfusion. Ann Surgery 216: 677-683.

[76] Yeh CG, Marsh HC, Jr., Carson GR, Berman L, Concino MF, Scesney SM, Kuestner RE, Skibbens R, Donahue KA, Ip SH (1991) Recombinant soluble human complement receptor type 1 inhibits inflammation in the reversed passive arthus reaction in rats. J Immunol 146: 250-256.

[77] Mulligan MS, Warren JS, Smith CW, Anderson DC, Yeh CG, Rudolph AR,Ward PA (1992a) Lung injury after deposition of IgA immune complexes: Requirements for CD18 and L-arginine.

[78] .Rabinovici R, Yeh CG, Hillegass LM, Griswold DE, DiMartino MJ, Vernick J,Fong K-L, Feuerstein G(1992) Role of complement in endotoxin/platelet-activating factor-induced lung injury. J Immunol 149: 1744-1750.

[79] Mulligan MS, Warren JS, Smith CW, Anderson DC, Yeh CG, Rudolph AR, Ward PA (1992a) Lung injury after deposition of IgA immune complexes: Requirements for CD18 and L-arginine.

[80] .Kaczorowski SL, Schiding JK, Toth CA, Kochanek PM (1995) Effect of soluble complement receptor-1 on neutrophil accumulation after traumatic brain injury in rats. J Cereb Blood Flow Metab 15:860-864.

[81] Piddlesden SJ, Jiang SS, Levin JL, Vincent A, Morgan BP (1996) Soluble complement receptor 1 (sCR1) protects against experimental autoimmune myasthenia gravis. J Neuroimmunol 71:173-177.

[82] .Piddlesden SJ, Storch MK, Hibbs M, Freeman AM, Lassmann H, Morgan BP(1994) Soluble recombinant complement receptor 1 inhibits inflammation and demyelination in antibody-mediated demyelinating experimental allergic encephalomyelitis. J Immunol 152:5477-5484

[83] .Lima MCR, Prouvost Danon A, eSilva PMR, Chagas MS, Calheiros AS, Cordeiro RSB, Latine D, Bazin H, Ryan USf, Fit Martins MA (1997) Studies on the mechanisms involved in antigen-evoked pleural inflammation in rats: Contribution of IgE and complement. J Leukocyte Biol 61: 286-292. 
[84] Regal JF, Fraser DG, Toth CA (1993) Role of the complement system in antigen-induced bronchoconstriction and changes in blood pressure in the guinea pig. J Pharmacol Exp Ther 267:979988.

[85] Pratt JR, Hibbs MJ, Laver AJ, Smith RAG, Sacks SH (1996a) Effects of complement inhibition with soluble complement receptor-1 on vascular injury and inflammation during renal allograft rejection in the rat. Am J Pathol 149: 2055-2066.

[86] .Pratt JR, Hibbs MJ, Laver AJ, Smith RA, Sacks SH (1996b) Allograft immune response with sCR1 intervention. Transpl Immunol 4: 72-75.

[87] .Baldwin WM III, Pruitt SK, Brauer RB, Daha MR, Sanfilippo F (1995)Complement in organ transplantation: Contributions to inflammation, injury, and rejection. Transplantation 59:797-808.

[88] Ryan US (1995) Complement inhibitory therapeutics and xenotransplantation. Nat Med 1: 967-968.

[89] Levin JL, Marsh HC, Jr., Rudolph AR (1996) sCR1, a novel complement inhibitor: Development and potential applications for treating hyperacute rejection of transplanted organs.in Principles of Drug Developmentin Transplantation and Autoimmunity, eds Lieberman R, Mukherjee A (R.G. Landes Company, Austin, Texas), pp 695-702.

[90] Moran P, Beasley H, Gorrell A, et al. Human recombinant soluble decay accelerating factor inhibits complement activation in vitro and in vivo. J Immunol. 1992; 149: 1736-43.

[91] .Christiansen D, Milland J, Thorley BR, et al. Engineering of recombinant soluble CD46: an inhibitor of complement activation. Immunol. 1996; 87: 348-54.

[92] Homeister JW, Lucchesi BR (1994) Complement activation and inhibition in myocardial ischemia and reperfusion injury. Annu Rev Pharmacol Toxicol 34: 17-40.
[93] Makrides SC, Ryan US (1997) Complement inhibition in ischemia reperfusion injury. in Ischaemia Reperfusion Syndrome, eds Grace PA, MathieRT, in press, Blackwell Science, Oxford.

[94] Buerke M, Murohara T, Lefer AM (1995) Cardio protective effects of a C1 esterase inhibitor in myocardial ischemia and reperfusion. Circulation 91: 393-402.

[95] Murohara T, Guo J, Delyani JA, Lefer AM (1995a) Cardio protective effects of selective inhibition of the two complement activation pathways in myocardial ischemia and reperfusion injury. Methods Find Exp Clin Pharmacol 17: 499-507.

[96] Horstick G, Heimann A, Götze O, Hafner G, Berg O, Böehmer P, Becker P,Darius H, Rupprecht H-J, Loos M, Bhakdi S, Meyer J, Kempski (1997).Intracoronary application of C1 esterase inhibitor improves cardiac function and reduces myocardial necrosis in an experimental model of ischemia and reperfusion. Circulation 95: 701-708.

[97] Arumugam TV, Shiels IA, Woodruff TM, Granger DN, Taylor $\mathrm{SM}$. The role of the complement system in ischemia-reperfusion injury. Shock. 2004; 21: 401-409.

[98] Huber-Lang MS, Sarma JV, McGuire SR, et al. Protective effects of anti-C5a peptide antibodies in experimental sepsis. FASEB J. 2001; 15: 568-70.

[99] .Wang Y, Rollins SA, Madri JA, Matis LA (1995) Anti-C5 monoclonal antibody therapy prevents collagen-induced arthritis and ameliorates established disease. Proc Natl Acad Sci USA 92: 8955-8959.

[100] Persidis, A., 1998. Complement inhibitors. Nat. Biotechnol. 16, $882 \pm 883$. 